\title{
PENGARUH PERLAKUAN PENGUSANGAN DENGAN UAP ETANOL TERHADAP PENURUNAN KUALITAS FISIOLOGI BENIH AKOR, MERBAU DAN MINDI
}

\author{
The Effect of Ageing With Ethanol Vapor on Physiological Qualities of Seeds of Akor (Acacia \\ auriculiformis), Merbau (Intsia bijuga) and Mindi (Melia azedarach)
}

\section{Zanzibar}

Balai Penelitian Teknologi Perbenihan Bogor

Jl. Pakuan Ciheuleut PO. BOX 105, Bogor - 16001, Telp./Fax. (0251) 327768

Naskah masuk: 27 November 2006 ; Naskah diterima: 29 Juni 2007

\begin{abstract}
The deterioration of seed quality is an inevitable natural process. This signifies the simultaneous decrease in the physiological activities within the seeds and renders them unviable. This research was intended to mimic the deterioration process by exposing the seeds with ethanol vapor. This ageing was carried out using fast ageing machine (MPC IPB 77-1) with ageing treatment of 5 min of exposure with ethanol vapor followed by 10 min exposure to hot air $\left(50^{\circ} \mathrm{C}\right)$. The treatments consisted of the level of ageing as indicated by number of ageing treatment applied to the seeds: 9, 12, 15, 18 and 21 times. The seeds were that of akor, merbau and mindi. The experiment was designed as a completely randomized design with seed quality variables included germination, growth uniformity and growth rate. Our results showed that ethanol vapor decreased seed quality. The decreased started at the ageing level 12 times for mindi, 15 times for merbau. As for akor seeds, the highest ageing lavel of 21 times had no significant effect on the seed quality but tend to decreased it. The decrease in germination capacity among those species varied. The highest decrease in the seed quality was for the variable of growth rate that is $44 \%$ for mindi, $22 \%$ from merbau and $17 \%$ for akor. Therefore, the stability of seed quality against unfavorable conditions varied among species and the highest was akor followed by merbau and mindi. This information may have significant implication for storage of these seeds.
\end{abstract}

Key words : akor, merbau, mindi, seed, physiological qualities, ethanol vapour, ageing

\begin{abstract}
ABSTRAK
Penurunan kualitas benih merupakan proses alami yang tidak dapat dihindari karena terjadi secara simultan hingga benih menjadi mati. Penelitian ini bertujuan mengetahui pengaruh uap etanol sebagai perlakuan devigorasi terhadap kemunduran kualitas fisiologi benih akor, merbau dan mindi. Faktor utama adalah pengusangan benih ; menggunakan mesin pengusang cepat (MPC IPB 77-1), dilakukan dengan cara : selama 5 menit benih diberi uap etanol $(90 \%)$, kemudian selama 10 menit dengan hembusan udara panas $\left(50{ }^{\circ} \mathrm{C}\right)$. Taraf pengusangan, terdiri dari : 9, 12, 15, 18, dan 21 kali. Parameter yang diamati adalah : daya berkecambah, keserempakan tumbuh dan kecepatan tumbuh benih. Rancangan percobaan menggunakan Rancangan Acak Lengkap (RAL). Hasil penelitian menunjukkan bahwa uap etanol berpengaruh buruk terhadap penurunan kualitas fisiologi. Penurunan tersebut dimulai pada taraf pengusangan 12 kali untuk benih mindi, 15 kali pada benih merbau, sedangkan pada benih akor meskipun hingga akhir pengusangan (21 kali) tidak berbeda nyata dengan kontrol, namun kualitasnya cenderung terus menurun. Besarnya kehilangan kapasitas perkecambahan antar jenis juga berbeda. Kehilangan kapasitas perkecambahan terbesar terjadi pada parameter kecepatan tumbuh. Pada benih mindi, merbau dan akor besarnya kehilangan tersebut berturut-turut adalah $44 \%, 22 \%$ dan $17 \%$. Ketahanan benih terhadap kondisi lingkungan yang tidak menguntungkan, khususnya selama penyimpanan (daya simpan), tertinggi pada benih akor, kemudian merbau dan mindi.
\end{abstract}

Kata Kunci : akor, merbau, mindi, benih, kualitas fisiologi, uap etanol, pengusangan 


\section{PENDAHULUAN}

Penurunan kualitas benih merupakan proses alami yang tidak dapat dihindari. Selama proses tersebut aktivitas dalam benih menurun hingga benih kehilangan semua viabilitasnya. Hal ini disebabkan oleh faktor dari dalam maupun atmosfir sekitar benih. Penurunan kualitas benih dapat diperlambat melalui penyimpanan yang tepat dengan memanipulasi faktor berpengaruh, yaitu kadar air dan suhu serta faktor-faktor penyerta lainnya, misalnya tekanan oksigen dan cahaya.

Salah satu cara mengetahui percepatan penurunan kualitas benih adalah melalui pengusangan dipercepat (accelerated ageing), misalnya simulasi pengusangan dengan uap etanol. Perlakuan uap etanol pada benih merupakan salah satu upaya devigorasi, yaitu benih ditempatkan pada kondisi yang tidak menguntungkan sehingga viabilitasnya cepat menurun. Menurut Pian (1981), uap etanol dapat diserap oleh benih dan pada konsentrasi tertentu akan berpengaruh buruk terhadap tampilan vigor benih. Uap etanol dapat menyebabkan perubahan sifat molekul makro yang berpengaruh terhadap aktivitas enzim, membran sel, mitokondria serta organel-organel sel lainnya yang berperan dalam metabolisme perkecambahan.

Simulasi pengusangan dengan uap etanol dapat dilakukan dengan mesin pengusang cepat (MPC IPB 77-1). Metoda pengusangannya adalah menghembuskan uap etanol $95 \%$ dan kemudian dengan uap panas kepada benih. Tingkat kemunduran yang diinginkan dapat diperoleh dengan mengatur waktu dan frekwensi pengusangan. Kartika (1984) melakukan penelitian menggunakan MPC IPB 77-1 untuk devigorasi benih mangium. Uap etanol dihembuskan selama 5 menit, kemudian dilanjutkan dengan hembusan uap panas selama 10 menit. Hingga taraf pengusangan 8 kali daya berkecambah hanya turun sebesar $2 \%$, namun vigor awalnya turun sebesar $40 \%$. Untuk mendapatkan gambaran secara lengkap penurunan kualitas fisiologi benih dibutuhkan taraf pengusangan yang lebih beragam.

Pengujian kualitas fisiologi benih yang hanya menggunakan parameter daya berkecambah memiliki keterbatasan dalam mendiskripsikan besaran relatif vigor dari suatu kelompok benih (seed lot). Selain daya berkecambah, parameter penting lainnya adalah kecepatan tumbuh, keserempakan tumbuh dan vigor spesifik. Nilai relatif dari ke tiga parameter tersebut sudah dapat mendiskripsikan kualitas kelompok benih, khususnya ketahanan benih selama disimpan serta tampilannya di lapangan. Menurut Sadjad (1993), benih berkualitas tinggi adalah benih yang mampu berproduksi normal pada kondisi sub-optimum dan diatas normal pada kondisi optimum. Hal ini harus nampak pada keseluruhan proses pertanaman, mulai dari menabur benih sampai tanaman tersebut berproduksi.

Penelitian ini bertujuan mengetahui pengaruh perlakuan uap etanol terhadap penurunan kualitas fisiologi benih akor, merbau dan mindi. Diketahuinya respon benih terhadap perlakuan ini maka dapat diketahui pula kemampuan benih terhadap kondisi yang kurang menguntungkan serta daya simpan masing-masing jenis.

\section{BAHAN DAN METODE}

Penelitian ini dilaksanakan di laboratorium Benih - IPB dan Rumah Kaca BPPTP Bogor, berlangsung mulai bulan Agustus hingga Desember 2004. Bahan-bahan yang digunakan antara lain benih, etanol (90 \%), tanah dan pasir. Alat yang digunakan antara lain: mesin pengusang cepat (MPC IPB 77-1), ragum, alat pembagi contoh benih, oven, timbangan analitik, alat pembagi benih, sprayer dan bak kecambah. 
Untuk mendapatkan contoh uji yang seragam terlebih dahulu dilakukan seleksi benih. Ciri-ciri khusus benih hasil seleksi adalah : (a) akor : berbentuk lonjong bernas, coklat kehitaman dan mengkilat (b) merbau : pipih berisi, kulit benih keras dan berwarna coklat-kehitaman, dan (c) mindi: kulit buah keras, berwarna putih dan tidak mengkerut. Benih hasil seleksi kemudian diusangkan dengan uap etanol.

Faktor utama adalah pengusangan dengan uap etanol (A), dilakukan dengan cara selama 5 menit benih diberi uap etanol $95 \%$ kemudian dilanjutkan dengan hembusan udara panas $\left(50^{\circ} \mathrm{C}\right)$ selama 10 menit (Kartika, 1984). Perlakuan ini diulang sesuai dengan taraf pengusangan yang diujikan. Taraf pengusangan terdiri dari :

- $\mathrm{a}_{1}=$ kontrol

- $\mathrm{a}_{2}=$ pengusangan sebanyak $9 \mathrm{kali}$

- $\mathrm{a}_{3}=$ pengusangan sebanyak $12 \mathrm{kali}$

- $\mathrm{a}_{4}=$ pengusangan sebanyak $15 \mathrm{kali}$

- $\mathrm{a}_{5}=$ pengusangan sebanyak $18 \mathrm{kali}$

- $\mathrm{a}_{6}=$ pengusangan sebanyak $21 \mathrm{kali}$

Benih yang telah diusangkan kemudian dikecambahkan di rumah kaca. Media tanam yang digunakan adalah campuran tanah dan pasir 1:1 (v/v) Ulangan dilakukan sebanyak 4 kali, setiap ulangan menggunakan 50 butir.

Rancangan percobaan untuk masing-masing jenis menggunakan rancangan acak lengkap (RAL) (Steel and Torrie, 1980). Parameter pengamatan terdiri dari : daya berkecambah (DB), keserempakan tumbuh $\left(\mathrm{K}_{\mathrm{st}}\right)$ dan kecepatan tumbuh $\left(\mathrm{K}_{\mathrm{ct}}\right)$ (Sadjad et al, 1999). Untuk mengetahui perbedaan yang nyata suatu nilai rata-rata dari parameter dilakukan uji lanjut Duncan.

\section{HASIL DAN PEMBAHASAN}

Dari data yang disajikan pada Tabel 1 diperoleh informasi bahwa perlakuan pengusangan dengan uap etanol berpengaruh buruk terhadap daya berkecambah benih mindi. Perlakuan juga berpengaruh pada keserempakan tumbuh benih merbau dan mindi, serta kecepatan tumbuh semua benih yang diuji. Pada Gambar 1 terlihat bahwa semakin lama periode pengusangan maka semakin menurunkan kapasitas perkecambahan.

Perlakuan uap etanol pada benih akor tidak mempengaruhi kapasitas perkecambahannya dibandingkan dengan kontrol, namun secara umum nilai dari semua parameter cenderung terus menurun. Terhadap parameter daya berkecambah perlakuan hanya berpengaruh pada benih mindi ; mulai taraf pengusangan 12 kali $\left(a_{3}\right)$ sudah berbeda nyata dengan kontrol (Gambar 1 a). Sampai akhir pengusangan $\left(\mathrm{a}_{6}\right)$, kehilangan daya berkecambah benih merbau, akor dan mindi masing-masing sebesar 10, 3 dan $25 \%$.

Keserempakan tumbuh benih merbau dan mindi sangat dipengaruhi oleh perlakuan uap etanol. Pada taraf pengusangan 12 kali $\left(a_{3}\right)$ untuk benih merbau dan 15 kali $\left(a_{4}\right)$ pada benih mindi, perlakuan sudah menunjukkan perbedaan yang nyata (Gambar 1 b). Sampai akhir pengusangan $\left(a_{6}\right)$, kehilangan keserempakan tumbuh benih merbau, akor dan mindi masing-masing sebesar 21, 7 dan $24 \%$. 
Tabel (Table) 1. Rekapitulasi Sidik Ragam (Uji F) Pengaruh Pengusangan dengan Uap Etanol terhadap Perkecambahan Benih Akor, Merbau dan Mindi (Summarized analysis of variance referring to ageing with ethanol vapor on the germination of akor, merbau and mindi seeds)

\begin{tabular}{|l|c|c|c|}
\hline \multirow{2}{*}{ Jenis (seed species) } & \multicolumn{3}{|c|}{$\begin{array}{c}\text { Nilai peluang perlakuan } \\
\text { (Value of treatments probability) }\end{array}$} \\
\cline { 2 - 4 } & DB (\%) & $\mathrm{KS}_{\mathrm{t}}(\%)$ & $\mathrm{KC}_{\mathrm{t}}(\mathrm{etmal})$ \\
\hline Akor & $1.18 \mathrm{~ns}$ & $1.29 \mathrm{~ns}$ & $2.78^{*}$ \\
\hline Merbau & $1.16 \mathrm{~ns}$ & $6.04 * *$ & $5.05^{* *}$ \\
\hline Mindi & $11.33^{* *}$ & $11.41 * *$ & $13.47^{* *}$ \\
\hline
\end{tabular}

Keterangan (Remarks) :

$\mathrm{DB}=$ persentase perkecambahan (germination percentage)

$\mathrm{KS}_{\mathrm{t}} \quad=$ keserempakan tumbuh (growth simultaneity)

$\mathrm{KC}_{\mathrm{t}} \quad=$ kecepatan tumbuh (growth rate)

** = berpengaruh nyata (significant effect), $\mathrm{P}=99 \%$

ns $\quad=$ tidak berpengaruh nyata (no significant effect)

Secara umum perlakuan dengan uap etanol berpengaruh buruk terhadap penurunan kualitas fisiologi benih. Parameter kecepatan tumbuh sangat peka oleh perlakuan ini dibandingkan parameter lainnya. Keadaan ini mengisyaratkan pentingnya melakukan perlakuan pendahuluan atau perlakuan pra perkecambahan lainnya, khususnya pada benih yang mengalami gejala dormansi. Selain itu, selama perkecambahan kondisi lingkungan harus dijaga tetap optimum karena pada kondisi yang buruk hal tersebut akan berakumulasi pada menurunnya perolehan kecambahan normal dan keseragaman pertumbuhan. Bewley dan Black (1985), proses kemunduran terjadi secara simultan hingga benih kehilangan semua viabilitasnya. Akumulasi kerusakan berdampak pada berkurangnya kapasitas perkecambahan ; vigor benih akan terus menurun yang dapat diamati pada kinerja kecepatan tumbuh, pembentukan dan keserempakan semai serta ketahanan terhadap stres. Sadjad (1993), penderaan dengan etanol merupakan faktor eksternal yang dapat menyebabkan abersi kromosom yang menghasilkan mutan seperti yang terjadi pada proses radiasi sehingga benih dapat menurun kualitasnya. 


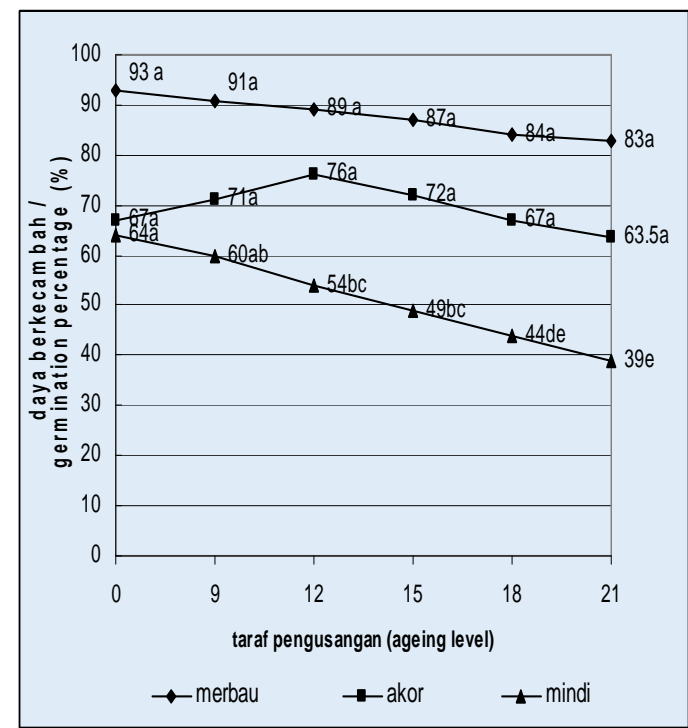

(a)

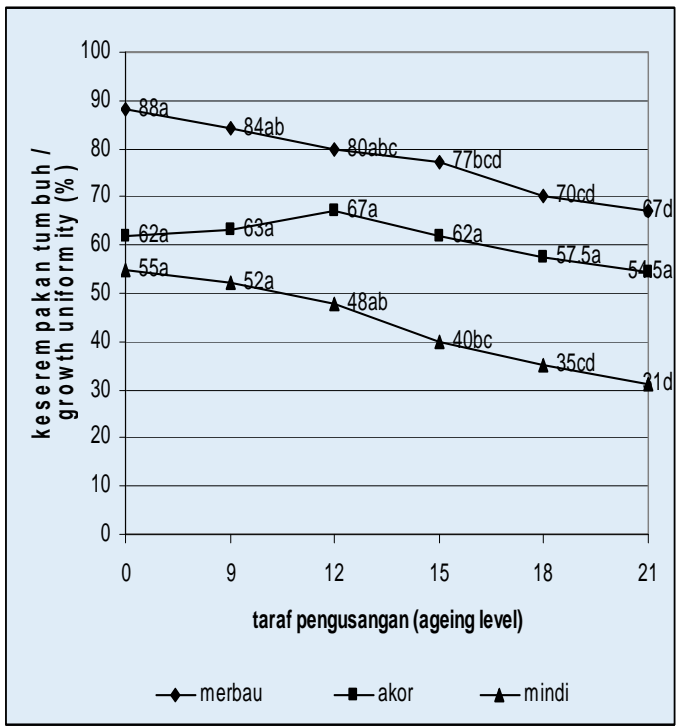

(b)

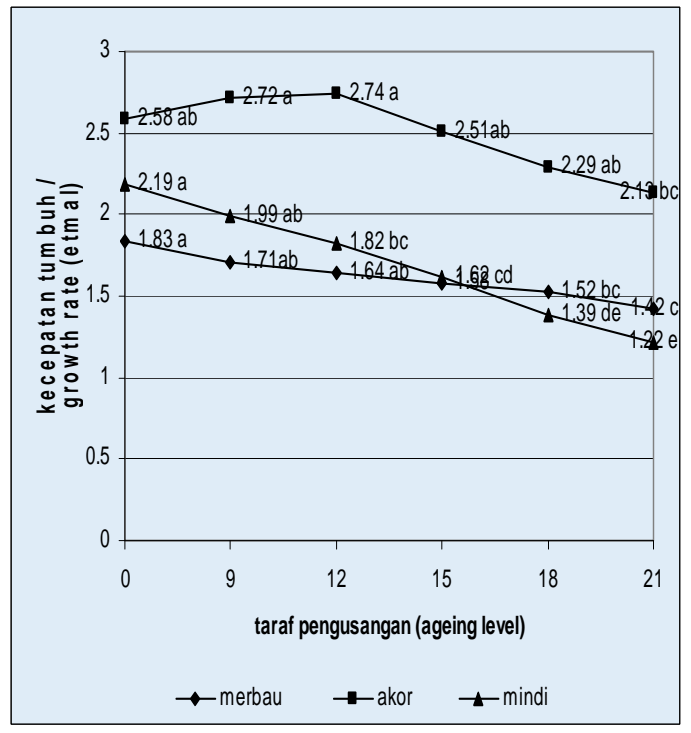

(c)

Gambar (Figure) 1. Penurunan kualitas fisiologis benih merbau, akor dan mindi akibat perlakuan uap etanol. (a) : daya berkecambah, (b) keserempakan tumbuh, (c) kecepatan tumbuh. Nilai yang diikuti oleh huruf yang sama pada jenis dan parameter yang sama tidak berbeda nyata pada selang kepercayaan $99 \%$. (Declining of physiological qualities in merbau, akor, and mindi seed brought about by ageing treatment using methanol vapor. Observed parameters: germination capacity (a), growth uniformity/simultanety (b), and growth rate (c. Figures followed with the same letters on the same species and parameters are not significantly different at $99 \%$ confidence interval. $a>b>c>d>e$ ) 
Tabel (Table) 2. Kehilangan Kapasitas Perkecambahan Benih Merbau, Akor dan Mindi pada Berbagai Taraf Pengusangan dengan Uap Etanol (Loss of germination capacity for merbau, akor and mindi seeds on ageing levels with ethanol vapor)

\begin{tabular}{|c|c|c|c|c|}
\hline \multirow[t]{2}{*}{$\begin{array}{c}\text { Jenis Benih (seed } \\
\text { species) }\end{array}$} & \multirow[t]{2}{*}{$\begin{array}{l}\text { Taraf penderaan } \\
\text { (ageing level) }\end{array}$} & \multicolumn{3}{|c|}{$\begin{array}{l}\text { Kehilangan kapasitas perkecambahan } \\
\text { (loss germination capacity) }\end{array}$} \\
\hline & & DB (\%) & KSt (\%) & KCt (\%) \\
\hline \multirow[t]{6}{*}{ Merbau } & 0 & 0 & 0 & 0 \\
\hline & 9 & -2 & -4 & -6.56 \\
\hline & 12 & -4 & -8 & -10.38 \\
\hline & 15 & -6 & -11 & -13.66 \\
\hline & 18 & -9 & -18 & -16.94 \\
\hline & 21 & -10 & -21 & -22.40 \\
\hline \multirow[t]{6}{*}{ Akor } & 0 & 0 & 0 & 0 \\
\hline & 9 & 4 & 1 & +5.43 \\
\hline & 12 & 9 & 5 & +6.20 \\
\hline & 15 & 5 & 0 & -2.71 \\
\hline & 18 & 0 & -4.5 & -11.24 \\
\hline & 21 & -3.5 & -7.5 & -17.44 \\
\hline \multirow[t]{6}{*}{ Mindi } & 0 & 0 & 0 & 0 \\
\hline & 9 & -4 & -3 & -9.13 \\
\hline & 12 & -10 & -7 & -16.89 \\
\hline & 15 & -15 & -15 & -26.03 \\
\hline & 18 & -20 & -20 & -36.53 \\
\hline & 21 & -25 & -24 & -44.29 \\
\hline
\end{tabular}

Keterangan (Remarks) :

$\mathrm{DB}=$ persentase perkecambahan (germination percentage)

$\mathrm{KS}_{\mathrm{t}} \quad=$ keserempakan tumbuh (growth simultanity)

$\mathrm{KC}_{\mathrm{t}}=$ kecepatan tumbuh (growth rate)

Percepatan penurunan kualitas fisiologi lebih awal dijumpai pada benih mindi, kemudian benih merbau dan akor. Selain lebih cepat penurunannya, kehilangan kapasitas perkecambahan pada masing-masing taraf pengusangan juga lebih besar (Tabel 2). Hal ini disebabkan kulit benih mindi (famili Meliaceae) tidak kedap terhadap air dan udara (Kamondo dan Kalangire, 1996 dalam Schmidt, 2000) ; pada kondisi lingkungan yang tidak menguntungkan, misalnya pada suhu dan kelembaban tinggi akan mudah sekali kehilangan viabilitasnya. Lain halnya benih merbau dan akor (famili Leguminosae) ; benih memiliki 3 lapisan kulit, dua lapisan kulit terluarnya yaitu kutikula dan palisade kedap terhadap air dan udara yang melindungi benih dari desikasi (Schmidt dan Joker, 2004). Kecepatan kemunduran dan hilangnya viabilitas bervariasi diantara jenis dan diantara individu benih dalam lot benih. Lot benih dari jenis yang sama dengan kualitas yang sama cenderung menunjukkan pola yang sama dalam penurunan viabilitas selama periode konservasi (Robert, 1983).

Percepatan kemunduran kualitas fisiologi juga sangat dipengaruhi komposisi biokimia benih. Dalam penelitian ini tidak dilakukan analisa kandungan biokimia, namun untuk menjelaskan mekanisme kemunduran tersebut didasarkan pada kandungan biokimia beberapa jenis dari famili yang sama (Samsuwida et al, 2002). Umumnya, benih Legum memiliki kandungan lemak yang rendah (4 - $9 \%$ ), sedangkan benih dari famili Meliaceae kandungan lemaknya relatif tinggi (40-60\%). Justice dan Bass (2002), benih berkadar lemak tinggi (oily seed) cenderung tidak tahan disimpan lama, terutama bila kandungan asam lemak tak jenuhnya pun tinggi. Proses oksidasi yang terjadi selama penyimpanan dapat memutuskan ikatan rangkap dari asam lemak tak jenuh sehingga menghasilkan radikel-radikel bebas yang dapat bereaksi dengan lipida lainnya menyebabkan rusaknya struktur 
membran sel. Dengan demikian percepatan kemunduran lebih awal dijumpai pada benih berlemak (oily seed) kemudian pada benih berprotein (protein seed) dan benih berkarbohidrat (starchy seed).

Pada taraf pengusangan 15 kali $\left(\mathrm{a}_{3}\right)$, perlakuan meningkatkan kapasitas perkecambahan benih akor. Daya berkecambah akan meningkat $9 \%$, keserempakan dan kecepatan tumbuh, masing-masing sebesar 5 dan 6 \%. Penelitian Zanzibar (2003) pada benih mangium juga ditemukan hal serupa. Pengusangan selama 240 jam pada suhu dan kelembaban tinggi $\left(t=40{ }^{\circ} \mathrm{C}, \mathrm{RH}=80-90 \%\right)$, daya berkecambah meningkat sebesar $10 \%$. Hal ini disebabkan uap etanol pada taraf tertentu maupun penggunaan suhu dan kelembaban tinggi mampu melunakkan kulit benih. Kedua cara ini dapat digunakan sebagai perlakuan pendahuluan benih Acacia spp.

Ketahanan benih terhadap perlakuan uap etanol juga menggambarkan ketahanan benih terhadap kondisi lingkungan yang tidak menguntungkan khususnya selama penyimpanan. Dengan demikian benih akor memiliki daya simpan tertinggi kemudian merbau dan mindi. Benih yang memiliki daya simpan tinggi, tidak membutuhkan perlakuan khusus selama penyimpanannya. Kadar air kesetimbangan benih akor dan merbau antara 6 - $8 \%$ (Yuniarti, 1997), sedangkan benih mindi 12,54 \% (Pramono dan Danu, 1989). Dengan demikian watak benih akor dan merbau (Bonner at al,1996) tergolong ortodoks kuat, sedangkan benih mindi berwatak subortodoks. Bewley dan Black (1982), menyatakan bahwa benih berwatak ortodoks kuat dapat disimpan pada tingkat kadar air sangat rendah (4- $8 \%$ ) yang sangat tergantung pada tingkat pengeringan. Air yang ada di dalam benih merupakan air makro yang tidak bergerak dan tidak mengalami reaksi kimia. Oleh sebab itu praktis tidak terjadi metabolisma ; benih tetap hidup tanpa manifestasi hidup yang terukur. Auld (1986), menyatakan bahwa Acacia spp dapat bertahan lama pada kondisi simpan lapangan, benih yang tertanam di dalam tanah selama 11 tahun masih tetap tumbuh, demikian halnya pada jenis merbau, sedangkan pada benih mindi (Danu dan Kurniawati, 1996) masa penyimpanannya tidak lebih dari 1 tahun pada ruang simpan kamar.

\section{KESIMPULAN}

Pengusangan dengan uap etanol mampu menurunkan kualitas fisiologi benih yang diteliti. Penurunan tersebut dimulai pada taraf pengusangan 12 kali untuk benih mindi, 15 kali pada benih merbau, sedangkan pada benih akor pada taraf pengusangan 21 kali. Daya simpan benih tertinggi yang merupakan fenomena terbalik dari perlakuan pengusangan berturut-turut pada benih akor, merbau dan mindi.

\section{DAFTAR PUSTAKA}

Auld, T. D. 1986. Population Dynamics of the Shrub Acacia suaveolens (Sm.) Willd Dispersal and Dynamics of the Soil Bank. Australia J. Ecol

Bewley, J. D. and M. Black. 1985. Seed Physiology of Development and Germination. Plenum Press. New York

Bonner, F. T. , J. A. Vozzo, W. W. Elam and S. B. Land Jr. 1996. Tree Seed Technology Training Course: Instructor's Manual. United State Departement of agriculture, Forest Service, Southern Forest Experiment Station. New Orleans.

Danu dan Kurniawati P.P. 1996. Pengaruh Kadar Air Awal Benih terhadap Daya Simpan Benih Mindi (Melia azedarach). Balai Litbang Teknologi Perbenihan. 
D. Syamsuwida, Naning Yuniarti, Enock Rohani K, Adang Muharam dan Endang Ismiati, 2002. Pengaruh Penurunan Kadar Air dan Penyimpanan terhadap Perubahan Fisiologis dan Biokimia Benih Ortodoks. Laporan Uji Coba. Balai Litbang Teknologi Perbenihan. Tidak diterbitkan

Justice, Oren L., dan Louis N. Bass. 2002. Prinsip dan Praktek Penyimpanan Benih (Terjemahan). PT. Raja Grafindo Persada. Jakarta

Kartika Elis, 1994. Penentuan Kriteria Vigor Bibit serta Pengaruh Tingkat Devigorasi dan Densitas Benih terhadap Keberhasilan Persemaian Paraserianthes falcataria dan Acacia mangium. Tesis Fakultas Pascasarjana. IPB Bogor.

Pian, Z.A. 1981. Pengaruh Uap Etil Alkohol terhadap Viabilitas Benih Jagung (Zea mays L.) dan Pemanfaatannya untuk Menduga Daya Simpan. Disertasi Fakultas Pasca Sarjana IPB. Bogor.

Pramono, A.A. dan Danu 1998. Teknik Pematahan Dormansi Benih Mindi (Melia azedarach). Balai Teknologi Perbenihan. Buletin Vol. 5 No. 3. 1998

Robert, E.H. 1983. Seed Deterorioration and Loss of Viability. In : Advances in research and Technology of Seeds. Pudoc, Wageningen.

Sadjad, S. 1993. Dari Benih kepada Benih. PT Gramedia Widiasarana Indonesia. Jakarta.

Sadjad, S., Endang Murniarti dan Satriyas Ilyas, 1999. Parameter Pengujian Benih dari Komparatif ke Simulatif. PT. Grasindo. Jakarta

Schmidt, L. 2000. Pedoman Penanganan Benih Tanaman Hutan Tropis dan Sub Tropis. Terjemahan. Ditjen RLPS. Departemen Kehutanan. Jakarta.

Schmidt, L dan Dorthe Joker, 2004. Kamus Biologi dan Teknologi Benih Tanaman Hutan. Ditjen RLPS. Departemen Kehutanan. Jakarta

Steel, R. G. D. and James H. Torrie. 1980. Prinsip dan Prosedur Statistika: Suatu pendekatan biometrik. Bambang Sumantri (pen.). 1989. Gramedia. Jakarta.

Yuniarti, N. 1997. Penentuan Cara Perlakuan Pendahuluan Benih Merbau Intsia bijuga. Balai Teknologi Perbenihan. Vol. 4. No. 2.

Zanzibar, M. 2003. Kemunduran Viabilitas Beberapa Benih Pohon Hutan Akibat Pengaruh Perlakuan Pengusangan. Buletin Teknologi Perbenihan Vol. 10 No. 1. Balai Litbang Teknologi Perbenihan. Bogor. 